\title{
Improved allometric equations for tree aboveground biomass estimation in tropical dipterocarp forests of Kalimantan, Indonesia
}

Solichin Manuri ${ }^{*}$ (D), Cris Brack ${ }^{1}$, Fatmi Noor'an², Teddy Rusolono ${ }^{3}$, Shema Mukti Anggraini ${ }^{3}$, Helmut Dotzauer ${ }^{4,5}$ and Indra Kumara ${ }^{6}$

\begin{abstract}
Background: Currently, the common and feasible way to estimate the most accurate forest biomass requires ground measurements and allometric models. Previous studies have been conducted on allometric equations development for estimating tree aboveground biomass (AGB) of tropical dipterocarp forests (TDFs) in Kalimantan (Indonesian Borneo). However, before the use of existing equations, a validation for the selection of the best allometric equation is required to assess the model bias and precision. This study aims at evaluating the validity of local and pantropical equations; developing new allometric equations for estimating tree AGB in TDFs of Kalimantan; and validating the new equations using independent datasets.
\end{abstract}

Methods: We used 108 tree samples from destructive sampling to develop the allometric equations, with maximum tree diameter of $175 \mathrm{~cm}$ and another 109 samples from previous studies for validating our equations. We performed ordinary least squares linear regression to explore the relationship between the AGB and the predictor variables in the natural logarithmic form.

Results: This study found that most of the existing local equations tended to be biased and imprecise, with mean relative error and mean absolute relative error more than 0.1 and 0.3 , respectively. We developed new allometric equations for tree AGB estimation in the TDFs of Kalimantan. Through a validation using an independent dataset, we found that our equations were reliable in estimating tree AGB in TDF. The pantropical equation, which includes tree diameter, wood density and total height as predictor variables performed only slightly worse than our new models.

Conclusions: Our equations improve the precision and reduce the bias of AGB estimates of TDFs. Local models developed from small samples tend to systematically bias. A validation of existing AGB models is essential before the use of the models.

Keywords: Allometric equation, Local and pantropical models, AGB, Model validation, Destructive sampling, Tropical dipterocarp forest

\footnotetext{
* Correspondence: solichin.solichin@anu.edu.au; solichin.manuri@gmail.com

${ }^{1}$ Fenner School of Environment and Society, The Australian National

University, Linnaeus Way Building 141, Canberra ACT, 2601, Australia

Full list of author information is available at the end of the article
} 


\section{Background}

Tropical dipterocarp forest (TDF) is one of the most important tropical ecosystems in the Indonesian archipelago. The forest harbours a high diversity of plant and animal species as well as a high density of carbon stock (MacKinnon 1996; Kartawinata 2005; Paoli et al. 2008). Over the last three decades, unsustainable management practices coupled with pressures from illegal logging, fires and plantation expansion have led to substantial rates of deforestation and degradation of natural forests (Hansen et al. 2009; Miettinen et al. 2011). This has greatly contributed to national greenhouse gas emissions (MoEF 2015).

To halt further forest losses, a performance-based incentive mechanism to reduce emissions from tropical deforestation and forest degradation (known as REDD+) has been discussed at a global forum (UNFCCC 2015). This mechanism, however, relies on accurate estimations of biomass stocks in forests (Asner 2011). Credible estimations on aboveground biomass (AGB) stocks and emission factors are essential data required for REDD+ reference emission levels, which is the benchmark for evaluating the performance of activities under the REDD + framework (IPCC 2006).

Most studies on forest biomass in tropical regions have been carried out using remote sensing technology, which provides wall-to-wall and consistent estimates across spatial, temporal and ecological variations (Avitabile et al. 2016; Halperin et al. 2016). However, this approach requires validation through ground measurement and appropriate allometric equations to convert tree metrics derived from field measurements into tree biomass. Many plot-level-based studies on AGB stock have been carried out for TDFs in Borneo (Berry et al. 2010; Griscom et al. 2014), mostly without destructive sampling efforts to validate existing or develop new equations. Some studies used existing local equations which developed from relatively small samples (Hiratsuka et al. 2006; Krisnawati et al. 2014). Unbiased allometric equation is essential for accurate estimates of forest AGB stocks and carbon emissions associated with deforestation and forest degradation activities at landscape level (van Breugel et al. 2011; Johnson et al. 2014).

Traditionally, AGB equations rely on the relationship between AGB and tree diameter, wood density and tree height (Chave et al. 2014), as well as the crown size (Henry et al. 2010; Goodman et al. 2014) as predictor variables. A large-scale tropical forest inventory campaign requires a simple and robust method to be implemented in a cost-effective and consistent way. Because of optical obstruction of the multi-layered canopies of dipterocarp forest, total tree height or crown measurements are relatively difficult, time consuming and subject to measurement errors. Several authors have suggested more practical solutions, including the use of the tree height-diameter model (Feldpausch et al. 2012) or bole height measurement, instead of total height measurement (Basuki et al. 2009).

The number of local or site-specific allometric studies in Indonesia is high compared with studies in other countries in South-East Asia (Yuen et al. 2016), including studies in the TDFs of Indonesian Borneo (Kalimantan) by Yamakura et al. (1986a), Basuki et al. (2009) and Hashimoto et al. (2004). The first two studies are the most well known and were conducted on TDFs with relatively large samples and a wide range of trunk diameter. Basuki et al. (2009) compared the locally developed equations with the pantropical equations and found that the mean percentage errors of the pantropical equations were more than $40 \%$ when applied to the local dataset. Yamakura's equations were constructed for each tree component rather than for the total tree, and thus can introduce bias if simply added together for estimating total tree AGB. Hashimoto et al. (2004) developed species-specific and mixed-species biomass equations for pioneer trees in a secondary forest in East Kalimantan. Although Hashimoto et al. (2004) study involved large sample size was $(N=108)$, the diameter range of the trunk was limited to a maximum of only $20.3 \mathrm{~cm}$. In addition, some pantropical equations were developed and widely used for estimating AGB in tropical regions, e.g. Brown (1997) and Chave et al. (2014). Both studies used large samples and a wide range of tree diameter compiled from tropical region, including Indonesia. Before the use of existing equations, a validation for the selection of the best allometric equation is required to assess the model bias and precision (Pearson et al. 2005).

Our interest lies in the validation and improvement of existing equations for more credible AGB estimations in TDFs. The study has three objectives: (1) to evaluate the validity of existing equations; (2) to develop new allometric equations in estimating tree AGB for TDFs in Kalimantan; and (3) to validate the new equations using independent datasets.

\section{Methods}

\section{Study sites}

This study was carried out in the tropical dipterocarp forests of Kalimantan. The tropical dipterocarp forest is one of the most important forest types in South East Asia and it provides high biodiversity and endemism, as well as economic values such as timber and important ecosystem services. As the name implies, the forests are dominated by some genera from the dipterocarp family, including Shorea spp., Dipterocarpus spp., Hopea spp., Parashorea spp., Anisoptera spp. and Dryobalanops spp. The trees are well known for their tall and emergent canopies and straight-bole commercial trunks. The field 
data were collected in primary forests of four timber concessions, that is, PT Erna Djuliati in Seruyan, PT Inhutani Nunukan, PT Intracawood Manufacturing in Malinau and PT Karya Rekanan Bina Bersama in Kapuas Hulu districts $\left(01^{\circ} 30^{\prime} 00^{\prime \prime} \mathrm{S}\right.$ to $04^{\circ} 02^{\prime} 22^{\prime \prime} \mathrm{N}$ and $112^{\circ} 03^{\prime} 00^{\prime \prime} \mathrm{E}$ to $\left.116^{\circ} 58^{\prime} 42^{\prime \prime} \mathrm{E}\right)$ at an elevation of $202-$ $540 \mathrm{~m}$ above sea level and a mean annual rainfall of 2936-3235 $\mathrm{mm}$.

\section{Data collection}

We carried out destructive samplings for AGB measurements in four timber concessions, in Malinau, Bulungan, Kapuas Hulu and Seruyan districts (Fig. 1). Forest compartments, in which we felled the sample trees were purposively selected following the current cutting plan. We identified the potential trees from previous forest inventory list. All large commercial non-deformed trees, with tree diameter $(D)$ greater than $80 \mathrm{~cm}$, from various species were first selected and the potential felling directions were estimated. To minimize the logging damage, we selected and felled small trees within the area that potentially will be impacted by the felling of large trees. We also selected trees from the potential logging and skidding roads. However, we excluded deformed trees and included a wide range of tree genera or family as much as possible.

Before the felling, we measured the $D$ (in $\mathrm{cm}$ ) at $1.3 \mathrm{~m}$ from the ground or at $20 \mathrm{~cm}$ above tree buttress. All trees were felled and fractioned into tree components: trunks, branches, twigs and leaves. All small stems and branches with $D \leq 30 \mathrm{~cm}$ and the twigs and leaves were weighed in the field using the OCS-L Crane digital scales with a capacity of 100 and $50 \mathrm{~kg}$. We estimated the volume of large stems and branches $(D>30 \mathrm{~cm})$ using the Smalian formula. We measured diameters over bark at the beginning and end of each $2-\mathrm{m}$ section. The end of the first section becomes the beginning of the second section and so on. All tree dimension measurements, including tree height $(H)$ and commercial bole height $(\hat{H})$, were measured using cloth tapes after tree felling, giving a relatively more accurate measurement than a standing tree measurement. Leaf voucher specimens were collected and shipped to the Research Center for Biology, Indonesian Institute of Sciences (Lembaga Ilmu Penengetahuan Indonesia; LIPI) for species identification.

\section{Laboratory analysis}

Wood and leaf samples of each component (disc or wedge-shaped samples for stems and branches) were collected and weighed, before being packed and transported to the nearest wood laboratories (i.e., Mulawarman University in East Kalimantan, Tanjungpura University in West Kalimantan and Bogor Agricultural University in
West Java) for dry weight and wood density analysis. Samples were dried in ovens at a temperature of $80^{\circ} \mathrm{C}$ or $105^{\circ} \mathrm{C}$ until achieving constant dry weights. The laboratory of Tanjungpura University measured the green wood volume of the sample using the water displacement method, and the labs of Mulawarman University and Bogor Agricultural University measured the volume of cube-shaped samples. $G$ was measured in $\mathrm{g} \cdot \mathrm{cm}^{-3}$. All field-measured volume data were converted into biomass by multiplying with the associated $G$ derived from laboratory analysis. We multiplied the fresh weight by the ratio of dry weight to fresh weight of the associated samples to derive dry weight or biomass values.

\section{Data analysis}

We carried out data analysis in three steps. First, we selected existing models developed from local and pantropical datasets which have been widely applied for AGB studies in Indonesia (Table 1). We evaluated the existing models using our destructive sampling dataset. We computed the mean relative error (MRE) and the mean absolute relative error (MARE) of each model using the following equations:

$$
\begin{aligned}
& M R E=\sum \frac{\mathrm{AGB}_{\mathrm{p}}-\mathrm{AGB}_{\mathrm{m}}}{\mathrm{AGB}_{\mathrm{m}}} \\
& \mathrm{MARE}=\sum\left|\frac{\mathrm{AGB}_{\mathrm{p}}-\mathrm{AGB}_{\mathrm{m}}}{\mathrm{AGB}}\right|
\end{aligned}
$$

where $A G B_{m}$ and $A G B_{p}$ are measured and predicted $A G B$, respectively. We also evaluated the performance of the models by regressing their $\mathrm{AGB}_{\mathrm{m}}$ against $\mathrm{AGB}_{\mathrm{p}}$. In a perfectly accurate relationship, this would be a linear relationship with an intercept of zero, a slope of one and a coefficient of determination of one.

Second, we transformed our AGB dataset into a natural logarithm to solve the heteroscedasticity problem of the data. We developed equations from a wide range of model forms to accommodate the availability of field data parameters. Several equation forms suggested by Chave et al. (2014) and Sileshi (2014) were selected. We performed ordinary least squares linear regression to explore the relationship between the AGB and the predictor variables, that is, $D, H, \hat{H}$ and $G$ in the natural logarithmic form. Correction factors calculated using Ratio Estimator (REst) (Snowdon 1991) were used to reduce systematic bias from back transformation. REst was calculated as $\left(\sum y_{i} / n\right) /\left(\sum \hat{y}_{i} / n\right)$, where $y_{i}$ and $\hat{y}_{i}$ are observed and predicted AGB of tree ${ }_{i}$ and $n$ is sample size. The selection of the best equations was based on the highest coefficient of determination $\left(r^{2}\right)$, the lowest root mean square error (RMSE) and the lowest corrected Akaike information criterion (AICc). AIC is particularly useful for model selection with small sample size, and 
Table 1 Local AGB equations from previous studies and their errors, when compared with our dataset

\begin{tabular}{|c|c|c|c|c|c|}
\hline Model Name & AGB Equations & MRE & MARE & Intercept (SE) & Slope (SE) \\
\hline$D_{\text {Bas }}$ (Basuki et al. 2009) & $\mathrm{AGB}=0.318 D^{2.196}$ & -0.210 & 0.370 & $-305(407)$ & $1.865^{\mathrm{b}}(0.084)$ \\
\hline$D_{\text {Bro }}$ Brown (1997) & $\mathrm{AGB}=42.69-12.8 D+1.242 D^{2}$ & 0.085 & 0.352 & $-469(411)$ & $1.345(0.006)$ \\
\hline$D_{\text {Bro2 }}$ (Brown 1997) & $A G B=\exp (-2.134+2.53 \ln D)$ & 0.043 & 0.321 & $576(393)$ & $0.961(0.045)$ \\
\hline DG Bas (Basuki et al. 2009) & $\mathrm{AGB}=0.4975 D^{2.188} G^{0.832}$ & -0.232 & 0.312 & $-602^{\mathrm{a}}(284)$ & $1.885^{\mathrm{b}}(0.057)$ \\
\hline$D \hat{H}_{\text {Bas }}$ (Basuki et al. 2009) & $\mathrm{AGB}=0.106 D^{2.03} \hat{H}^{0.542}$ & -0.345 & 0.392 & $-358(410)$ & $2.145^{b}(0.098)$ \\
\hline$D_{\text {Has }}$ (Hashimoto et al. 2004) & $A G B=0.08127 D^{2.44}$ & -0.495 & 0.508 & $353(395)$ & $2.196^{b}(0.101)$ \\
\hline DH Yam (Yamakura et al. 1986a) & $\begin{array}{l}B_{\mathrm{s}}=0.02909\left(D^{2} H\right)^{0.9813} \\
B_{\mathrm{b}}=0.1192\left(B_{s}\right)^{1.059} \\
B_{1}=0.09146\left(B_{s}+B_{\mathrm{b}}\right)^{0.7266} \\
\mathrm{AGB}=\left(0.02909\left(D^{2} H\right)^{0.9813}+0.1192\right. \\
\left(0.02909\left(D^{2} H\right)^{0.9813}\right)^{1.059}+0.09146\left(\left(0.02909\left(D^{2} H\right)^{0.9813}\right)+\right. \\
\left.\left(0.1192\left(0.02909\left(D^{2} H\right)^{0.9813}\right)^{1.059}\right)\right)^{0.7266}\end{array}$ & -0.087 & 0.320 & $1185^{\mathrm{a}}(385)$ & $0.933^{b}(0.045)$ \\
\hline$D G H_{\text {Cha }}$ & $0.0673\left(D^{2} G H\right)^{0.976}$ & 0.002 & 0.216 & $813^{\mathrm{a}}(264)$ & $0.875^{\mathrm{b}}(0.027)$ \\
\hline
\end{tabular}

${ }^{a}$ and ${ }^{b}$ denote significant difference to 0 and 1, respectively. AGB is in $\mathrm{kg} . D$ is tree diameter (cm), $H$ is total tree height (in $\mathrm{m}$ ), $\hat{H}$ is commercial bole height (in $\mathrm{m}$ ) and $G$ is wood density (in $\mathrm{gr}^{\mathrm{cm}^{-3}}$ ). Values in parentheses are standard errors

the corrected-version AICc provide better performance than AIC (Hurvich and Tsai 1989).

Third, we validated our developed equations using independent datasets. Two independent datasets, derived from previous studies by Yamakura et al. $(n=69)$ and Samalca (2007) $(n=40)$, were used for this analysis. The datasets had previously been used for the development of site-specific allometric models by Yamakura et al. (1986a) and Basuki et al. (2009), respectively, which were compared in the first step. Similar to the first step, we computed the MRE and MARE of our selected models and the existing local models. In addition, we performed a regression analysis to fit the $A_{G B}$ and the $A G B_{p}$ of all models to evaluate further the precision and bias of the models (Piñeiro et al. 2008).

\section{Results}

The dataset used for developing and validating AGB models covered a wide range of diameter, height, wood density and tree species (Additional file 1). A total of 108 sample data were collected from destructive harvesting in East, Central and West Kalimantan. The largest tree had a diameter of $172 \mathrm{~cm}$ and a total height of 75 m. Fifty per cent of the samples were trees with $D>50$ $\mathrm{cm}$, while trees with $D>100$ accounted for $10 \%$ of the total samples $(n=11)$. The dataset consisted of 80 species from 27 families. Thirty per cent of total felled trees were from the dipterocarp family.

\section{Accuracy of the existing equations}

We evaluated the precision and bias of previously published local AGB equations using our dataset. Most of the previously published equations had an MRE and MARE of more than 0.21 and 0.31 , respectively. Only $D H_{\text {Yam }}$ had an MRE of less than 0.1 and a slope close to 1 (Table 1). The pantropical equations performed better than the existing local equations. The MRE of all pantropical equations were less than 0.1. $D G H_{\text {Cha }}$ had the smallest MARE among the existing equations. However, only $D_{\mathrm{Bro} 2}$ had the deviation of less than 5\% (slope of 0.964).

The regression analysis between the log-transformed measured AGB and the log-transformed predicted AGB of existing local equations showed an underestimated trend, especially the $D G_{\mathrm{Bas}}$ and $D_{\mathrm{Has}}$ models (Fig. 2). The $D_{\text {Has }}$ model, which was developed from a low range of tree diameter from secondary succession, failed to accurately estimate the tree AGB from primary TDFs. $D_{\text {Has }}$ showed a systematic bias at all diameters. The regression lines of $\operatorname{Ln} D_{\text {Bas }}$ and $\operatorname{Ln} D \hat{H}_{\text {Bas }}$ depicted underestimation of small trees and overestimation of large trees, with the points of intersection at 5.15 and 5.24, respectively.

\section{New aboveground biomass equations for tropical dipterocarp forests}

Table 2 depicts the indicators of model fit obtained by using model forms with different predictor variables, after back transformation from a logarithmic form using REst correction factor. All residual plot of the linear models showed normal distributions (Additional file 1). The DGH and DG models explained more than $90 \%$ of tree AGB variation, while the $D$ and $D H$ models explained less than $90 \%$ of the variation. Based on the AIC, RMSE and adjusted $r^{2}$ values (Table 2) and considering the plots of predicted against the observed Ln AGB (Fig. 2), we selected the best models with combinations of variables, these are: $D 1, D H 3, D \hat{H} 5, D G 8, D G H 9$ and $D G \hat{H} 10$. However, the inclusion of $\hat{H}$ as predictor variable did not improve the performance of the equations significantly. $D \hat{H} 5$ had lower AICc but higher RMSE compared to the $D 1$, while the $D G \hat{H} 10$ performed worse than $D G 8$. 


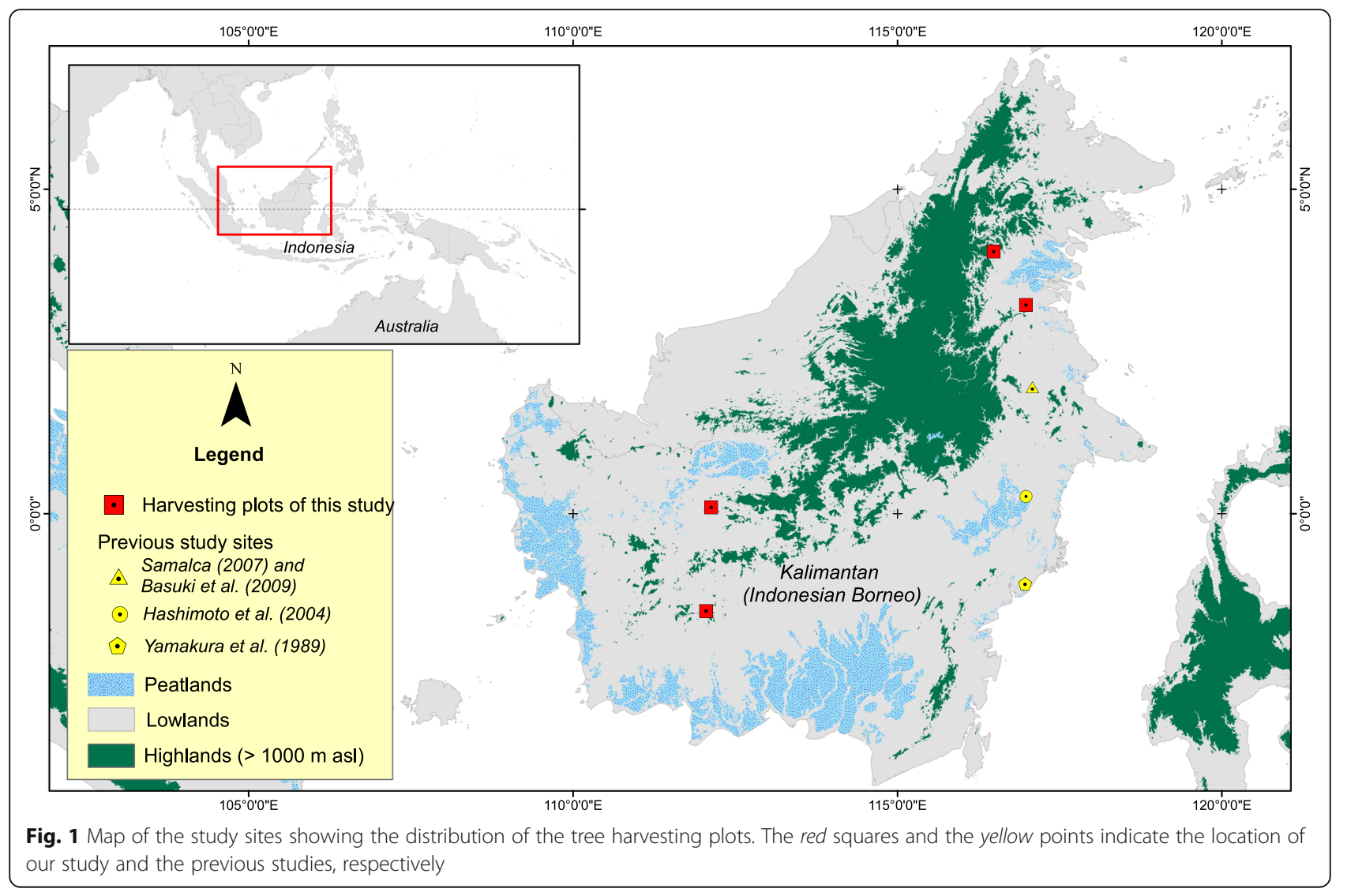

\section{Model validation}

We validated our equations using datasets from independent datasets. We found significantly different results between our models and most of the existing local models. Our models outperformed local models considerably. Both $D_{\text {Bas }}$ and $D G_{\text {Bas }}$ equations showed underestimation trends, even when applied to their own dataset, in particular for the large trees (Fig. 3). Although both models have relatively normal precisions, the biases of the models are very large (Table 3). For example, $D G_{\text {Bas }}$ has MRE and MARE of -0.042 and 0.304 , respectively, with the slope of the regression between observed and predicted AGB close to two. Slopes of two indicate large bias, whereas the estimates are twice smaller than the predicted, if the intercepts are zero. $D_{\text {Bas }}, D_{\text {Bro }}$ and $D H_{\text {Yam }}$ had negative intercepts that significantly different to zero, suggesting the overestimation of small trees. In contrast, DG8 and DGH9 had intercepts that were not significantly different to zero and slope more than 0.95 , indicating bias of less than $5 \%$.

Only the $D H_{\text {Yam }}$ model that had lower MRE and MARE than our model that has the same predictor variables (Table 3, Fig. 3). The reason could be that the dataset used for developing $D H_{\text {Yam }}$ was the validation dataset in this study. However, the deviation of the estimated AGB using $D H_{\text {Yam }}$ was larger than the deviation from our $D H 3$ model, indicated by the intercept that was different from zero and the greater slope. This large deviation was mainly due to the underestimation of large trees and overestimation of small trees (Fig. 3). $D H_{\text {Yam }}$ used a complex model form because it was originally developed for estimating biomass of tree components (Table 1). Similarly, $D G H_{\text {Cha }}$ and our $D G H 9$ model had comparable MRE and MARE values, with deviation from the actual estimates 11.1 and $4.6 \%$ respectively.

\section{Discussions}

Our new AGB equations outperformed all existing local equations. Most of the local models tended to have a systematic errors, potentially due to field measurement errors or biased samples. The existing pantropical equations performed only slightly worse than our new equations. The $D G H_{\text {Cha }}$ in particular, performed consistently well when applied to our dataset and the validation data. $D G H_{\text {Cha }}$ was developed using large number of samples from Borneo, including the validation dataset used in this study (Chave et al. 2014). Therefore previous studies on forest aboveground biomass stocks in TDF of Kalimantan or Borneo using $D G H_{\text {Cha }}$ should be valid.

Our DGH9 model performs better than other models, with lower bias and better precision. Individual tree height measurements in closed-canopy 

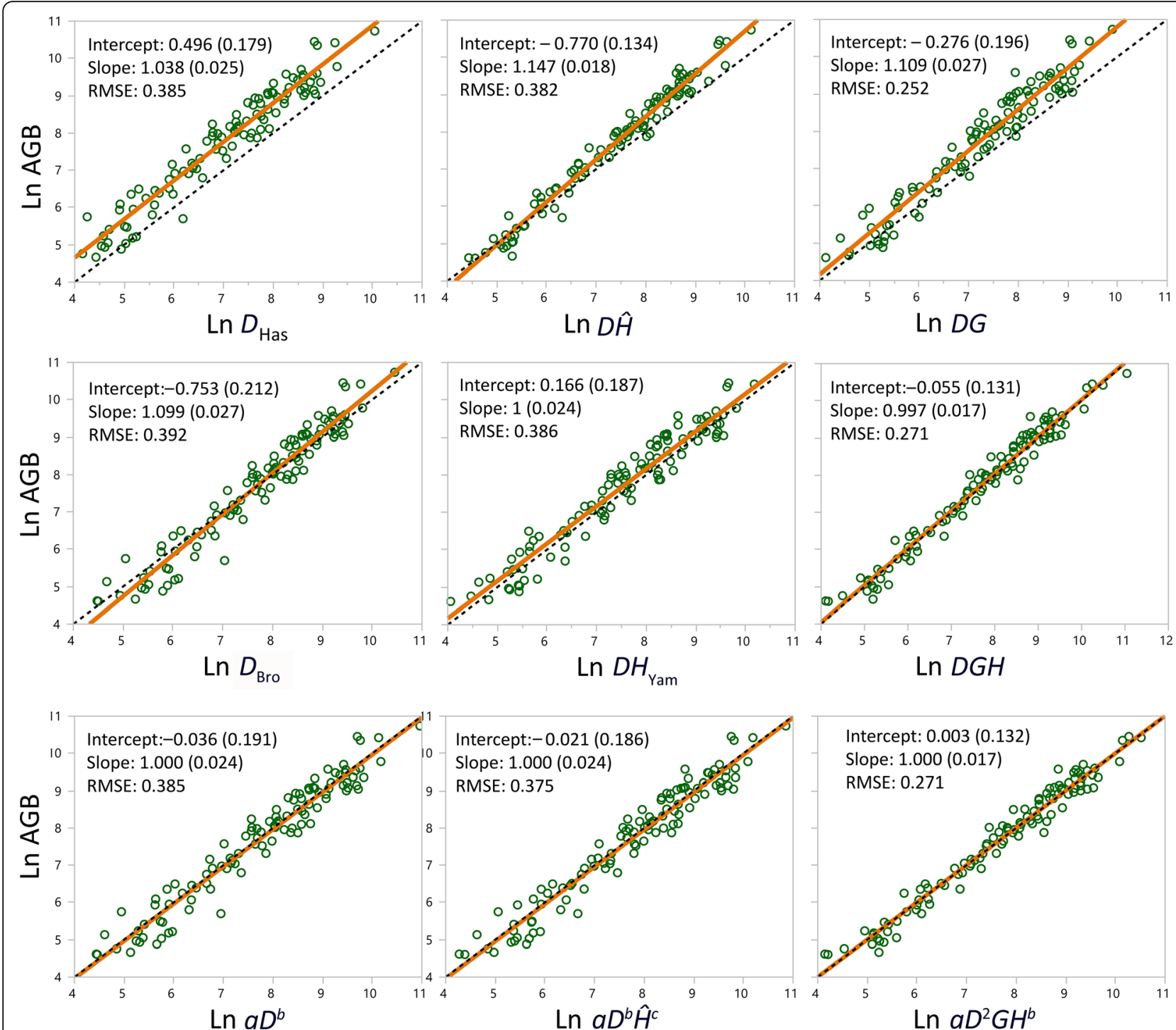

Fig. 2 Regression analysis of $L n$-measured AGB and Ln-predicted AGB. The upper and lower figures depicted results of existing local equations and the new equations, respectively. Numbers in parentheses were the standard deviation

TDFs are difficult and thus have high uncertainty. In that case, the DG8 should be used. However, due to a very high diversity of tree species in the TDF, identification of tree taxonomy could be problematic. Tree taxonomy identification during forest inventory for large area creates logistical and financial burden for the collection, shipment and identification of the herbarium specimens. For timber extraction planning purpose, tree identification was commonly carried out only using local names without involving botanist, and thus difficult to obtain accurate wood density values from the existing wood databases. Therefore, for estimating AGB from existing timber inventory dataset, we suggested to use the $D 1$ or $D \hat{H} 5$ (if the bole height is available).
AGB models developed from a small number of samples and limited tree diameter range have the potential risk to be biased, especially when applied beyond their sample characteristic as well as geographical, biophysical and forest boundaries (van Breugel et al. 2011; Manuri et al. 2014). However, although the samples used by Basuki et al. (2009) were sufficient in number and diameter range, their models were not able to predict AGB accurately, even using the dataset they partly used for the models development. We suspect these inaccuracies are due to differences in sampling strategy (e.g., sample selection), assumptions in model development (e.g., correction factor) or approach in AGB field measurements (e.g., assumptions of regular shapes of stems and branches with diameter more than $15 \mathrm{~cm}$ ). 
Table 2 The parameter estimates and indicators of model fit from new AGB equations

\begin{tabular}{|c|c|c|c|c|c|c|c|c|c|}
\hline \multirow{2}{*}{$\begin{array}{l}\text { Model } \\
\text { ID }\end{array}$} & \multirow[t]{2}{*}{ Equations } & \multicolumn{4}{|c|}{ Parameter estimates } & \multirow[t]{2}{*}{$n$} & \multirow[t]{2}{*}{ Adj..$^{2}$} & \multirow{2}{*}{$\begin{array}{l}\text { RMSE } \\
(\mathrm{kg})\end{array}$} & \multirow[t]{2}{*}{$\mathrm{AlCc}$} \\
\hline & & $a$ & $b$ & c & $d$ & & & & \\
\hline$D 1$ & $0.125 D^{2.533}$ & $0.125(0.033)$ & $2.533(0.062)$ & & & 108 & 0.821 & 3215 & 2061 \\
\hline D2 & $\begin{array}{l}\operatorname{Exp}(-2.845+2.726(\operatorname{Ln} D)-0.094 \\
\left.(\operatorname{Ln} D)^{2}-0.271(\operatorname{Ln} D)^{3}\right) \times 1.071\end{array}$ & $-2.845(0.479)$ & $2.726(0.122)$ & $-0.094(0.104)$ & $-0.271(0.141)$ & 108 & 0.810 & 3303 & 2061 \\
\hline$D H 3$ & $0.068 D^{2.268} H^{0.483}$ & $0.068(0.027)$ & $2.268(0.215)$ & $0.483(0.200)$ & & 108 & 0.813 & 3281 & 2053 \\
\hline $\mathrm{DH} 4$ & $0.041\left(D^{2} H\right)^{0.986}$ & $0.041(0.013)$ & $0.986(0.024)$ & & & 108 & 0.804 & 3358 & 2064 \\
\hline DH5 & $0.086 D^{2.388} \hat{H}^{0.326}$ & $0.086(0.027)$ & $2.388(0.084)$ & $0.326(0.132)$ & & 108 & 0.823 & 3191 & 2059 \\
\hline DH6 & $0.05\left(D^{2} \hat{H}\right)^{1.011}$ & $0.050(0.016)$ & $1.011(0.027)$ & & & 108 & 0.798 & 3409 & 2068 \\
\hline DG7 & $0.236 D^{2.5} G^{1.079}$ & $0.236(0.042)$ & $2.500(0.040)$ & $1.079(1.079)$ & & 108 & 0.918 & 2180 & 1971 \\
\hline$D G 8$ & $0.277\left(D^{2} G\right)^{1.238}$ & $0.277(0.042)$ & $1.238(0.019)$ & & & 108 & 0.924 & 2095 & 1963 \\
\hline DGH9 & $0.071\left(D^{2} G H\right)^{0.973}$ & $0.071(0.014)$ & $0.973(0.016)$ & & & 108 & 0.909 & 2287 & 1981 \\
\hline DGĤ10 & $0.093\left(D^{2} G \hat{H}\right)^{0.994}$ & $0.093(0.021)$ & $0.994(0.020)$ & & & 108 & 0.895 & 2452 & 1997 \\
\hline
\end{tabular}

Correction factors had been incorporated into the equations. The models presented in bold are the best equations from each model type. Values in parentheses are the standard errors

In contrast with the dataset used by Basuki et al. (2009), which used only 40 species, our total number of species was doubled. The percentage of dipterocarp trees in the Basuki et al. (2009) dataset was more than $50 \%$, while we had only $30 \%$. Our dataset composition seems to be more similar to the floristic composition in the primary dipterocarp forests, with a percentage of total trees of about 25\% (Sist and Saridan 1999). In Danum Valey, the dipterocarps population accounted for only $16 \%$ of total trees sampled in the primary dipterocarp forests. Nevertheless, they dominated the forest, representing about $50 \%$ of the basal area owing to their large and emergent trees (Newbery et al. 1992).

Basuki et al. (2009) calculated the biomass of stems and branches, which diameter greater than $15 \mathrm{~cm}$, using volume-based measurement, while we weighed all stems and branches that had a diameter of less than $30 \mathrm{~cm}$ or had irregular shapes, other than a cylindrical shape. Therefore, we also weighed most of the irregular stumps. The kernel smoother line representing the error distribution of $D_{\text {Bas }}$ model across Ln $A G B$, intersected at the value of 4.7 with the zero line (Fig. 3) which equals $110 \mathrm{~kg}$ of $\mathrm{AGB}$ or $14.3 \mathrm{~cm}$ of tree diameter. This suggested that the $D_{\mathrm{Bas}}$ equation tend to underestimate the AGB of trees with diameter of more than $14.3 \mathrm{~cm}$. This supports our supposition regarding the possible error of biomass measurement of trunks or branches with diameters greater than $15 \mathrm{~cm}$. Such different approaches or assumptions in field measurement might introduce bias. Differences in the destructive sampling method used in independent research are unavoidable (Manuri et al. 2014, under review), which may lead to incomparable tree biomass datasets. Thus, standardised methods for principal measurement components are required to ensure the measured datasets are valid. Such related initiatives have been carried out globally (Picard et al. 2012) and nationally (BSN 2011).

Some of our wood samples have exceptionally large values of wood density $\left(>1 \mathrm{gr} \cdot \mathrm{cm}^{-3}\right)$ compared to the existing wood density databases. For example the 45 cm-diameter Dipterocarpus stellatus has wood density of $1.3 \mathrm{gr} \cdot \mathrm{cm}^{-3}$, which is greater than any records from Dipterocarpus genus. We checked the field and laboratory records, and did not find any inconsistencies in the measurements. This species is endemic to Borneo. We did not find any record of the wood density from this species from the existing wood density databases. Soerianegara and Lemmens (1993) and Zanne et al. (2009) recorded the highest wood density from Dipterocarpus genus were 1.07 and 0.89 , respectively. There are two possible main reasons that explain this. First, wood density variation occurs among individual within species (Henry et al. 2010), which influenced by tree diameter size and guild status (Henry et al. 2010; Iida et al. 2012), climatic variables (Onoda et al. 2010) and soil fertility (Muller-Landau 2004). Second, there are some differences in the method for wood density measurement between tree biomass and wood characteristic studies. Our wood density measurement involves wedge or pie-shaped samples, which include barks, from various trunk sections and tree compartments. This is to ensure that the measured wood densities are closed to the actual values of tree wood densities (Williamson and Wiemann 2010).

A validation of existing AGB models is essential before the use of the models. We found that the use of MRE and MARE are not sufficient for evaluating the AGB model performance, since they only represent the mean 


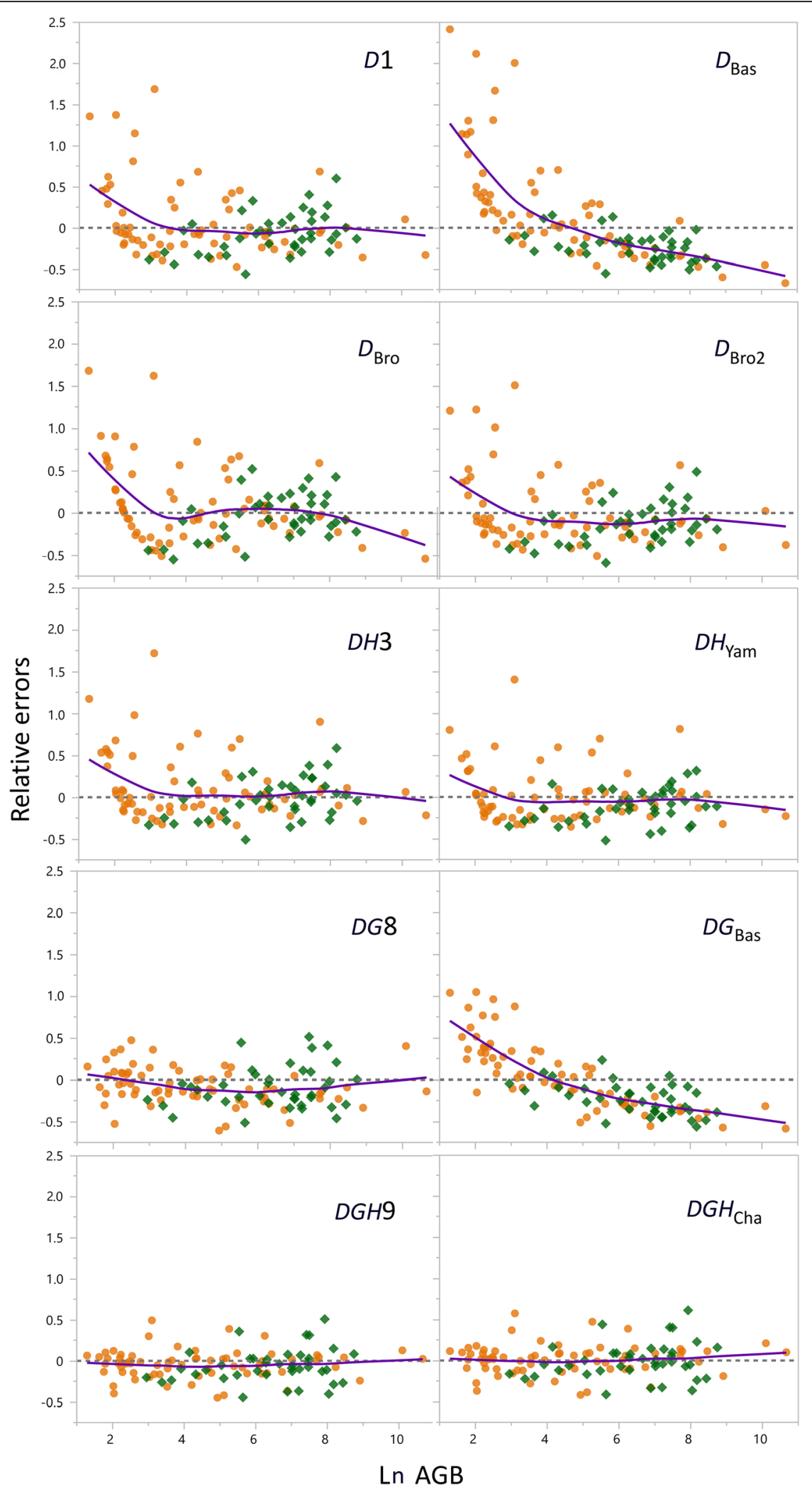

Fig. 3 Relative error distribution of the existing and new models. The orange circles and the green diamonds represent the datasets from Yamakura et al. and Samalca (2007) datasets, respectively. The solid purple curves were generated using lowess method 
Table 3 Model validation using datasets from previous studies

\begin{tabular}{|c|c|c|c|c|c|c|}
\hline Model ID & Adj..$^{2}$ & RMSE (kg) & MRE & MARE & Intercept (SE) & Slope (SE) \\
\hline D1 & 0.935 & 1220 & 0.025 & 0.265 & $-123(123)$ & $1.201^{\mathrm{b}}(0.030)$ \\
\hline $\mathrm{DH} 3$ & 0.971 & 819 & 0.069 & 0.240 & $-142(83)$ & $1.133^{\mathrm{b}}(0.019)$ \\
\hline DG8 & 0.941 & 1157 & -0.084 & 0.202 & $113(115)$ & $0.955^{b}(0.023)$ \\
\hline DGH9 & 0.993 & 395 & 0.049 & 0.142 & $66(39)$ & $0.954^{\mathrm{b}}(0.008)$ \\
\hline$D_{\text {Bas }}$ & 0.915 & 1392 & 0.056 & 0.383 & $-438^{a}(144)$ & $2.349^{b}(0.069)$ \\
\hline$D_{\text {Has }}$ & 0.932 & 1253 & -0.486 & 0.507 & $-202(127)$ & $2.890^{\mathrm{b}}(0.075)$ \\
\hline$D_{\text {Bro }}$ & 0.908 & 1453 & 0.053 & 0.289 & $-437^{a}(150)$ & $1.669^{b}(0.051)$ \\
\hline$D_{\text {Bro2 }}$ & 0.935 & 1221 & 0.043 & 0.272 & $-125(123)$ & $1.295^{b}(0.033)$ \\
\hline$D G_{\text {Bas }}$ & 0.937 & 1197 & -0.042 & 0.304 & $-206(121)$ & $1.946^{b}(0.048)$ \\
\hline$D H_{\text {Yam }}$ & 0.988 & 514 & -0.025 & 0.217 & $-137(52)^{a}$ & $1.243^{b}(0.013)$ \\
\hline$D G H_{\text {Cha }}$ & 0.993 & 395 & 0.005 & 0.146 & 71 (39) & $0.889^{b}(0.007)$ \\
\hline
\end{tabular}

and ${ }^{\mathrm{b}}$ denote significant difference to 0 and 1 , respectively

errors, not the trend of the residuals. To address this gap, a simple linear regression analysis between the observed and predicted values of the models is required to quantify the general tendency of the residuals (Piñeiro et al. 2008). The $r^{2}$ and RMSE indicate the precision of the estimates, while the slope and the intercept of the fitted line describe the bias of the estimates.

\section{Conclusion}

Most of the existing local AGB equations tend to be biased and imprecise. Local models developed from small samples tend to systematically biased. We recommend to not using the local models for estimating AGB or to validate prior their use especially if the models were developed from other region outside the study site, even within the same forest type. We developed new allometric equations for tree AGB estimation in the TDFs of Kalimantan using a relatively large dataset with a maximum tree diameter of 175 $\mathrm{cm}$. Through a validation using independent datasets, we found that our equations improve the precision and reduce the bias of AGB estimates.

\section{Additional file}

Additional file 1: Tree samples, regression outputs and residual plots. (DOCX $238 \mathrm{~kb}$ )

\section{Acknowledgements}

The authors are grateful to the GIZ-Forclime project, a bilateral project between Indonesia and German governments, for funding the field measurements. We would like to thank Pak Giono, Pak Tokarena and Erik Somala for felling permits, logistics arrangement and field data collection. We also acknowledge the support from the timber concessions (i.e., PT Karya Rekanan Bina Bersama, PT Intracawood Manufacturing, PT Inhutani I and PT Erna Djuliawati) in providing access to cut the trees. We thank Julie Watson for their critical reading of the previous manuscript, Elite Editing for proof reading of the draft manuscript and the two anonymous reviewers for their insightful comments and suggestions to improve the manuscript. Solichin Manuri gratefully acknowledges the support of Australia Award Scholarship from 2013 to 2017.

Availability of data and materials

Raw data is available in the Additional file 1.

Competing interests

The authors declare that they have no competing interests.

\section{Authors' contributions}

SM, TR formulated the idea and design sampling method. CB and HD supervised the study. SM, FN, SMA and IK collected field data and carried out laboratory analysis. SM performed data analyses and wrote the manuscript. All authors reviewed and revised the manuscript. All authors read and approved the final manuscript.

\section{Author details}

${ }^{1}$ Fenner School of Environment and Society, The Australian National University, Linnaeus Way Building 141, Canberra ACT, 2601, Australia. ${ }^{2}$ Dipterocarps Research Center, Forest Research Development and Innovation Agency, Ministry of Environment and Forestry, Jl. AW Syahrani, Samarinda,

East Kalimantan, Indonesia. ${ }^{3}$ Faculty of Forestry, Bogor Agricultural University, II Raya Darmaga, Kampus IPB, Bogor 16680, Indonesia. ${ }^{4}$ Forests and Climate Change Program, Deutsche Gesellschaft für Internationale Zusammenarbeit (FORCLIME-GIZ), Manggala Wanabakti Building, Block VII, 6th floor, Jakarta, Indonesia. ${ }^{5}$ Biodiversity and Climate Change Program, Deutsche Gesellschaft für Internationale Zusammenarbeit (BIOCLIME-GIZ), Manggala Wanabakti Building, Block VII, 6th floor, Jakarta, Indonesia. ${ }^{6}$ District Forestry and Plantation Service, J. Antasari No 4 Putussibau, Kapuas Hulu 78711, West Kalimantan, Indonesia.

Received: 29 July 2016 Accepted: 28 November 2016

Published online: 14 December 2016

\section{References}

Asner GP (2011) Painting the world REDD: addressing scientific barriers to monitoring emissions from tropical forests. Environ Res Lett 6:021002 Avitabile V, Herold M, Heuvelink G, Lewis SL, Phillips OL, Asner GP, Armston J, Ashton PS, Banin L, Bayol N (2016) An integrated pan-tropical biomass map using multiple reference datasets. Global Change Biol 22(4):1406-20

Basuki TM, van Laake PE, Skidmore AK, Hussin YA (2009) Allometric equations for estimating the above-ground biomass in tropical lowland Dipterocarp forests. Forest Ecol Manage 257:1684-1694

Berry NJ, Phillips OL, Lewis SL, Hill JK, Edwards DP, Tawatao NB, Ahmad N, Magintan D, Khen CV, Maryati M (2010) The high value of logged tropical forests: lessons from northern Borneo. Biodivers Conserv 19:985-997

Brown S (1997) Estimating biomass and biomass change of tropical forests a primer. Food and Agriculture Organization of the United Nations. Rome 
BSN (2011) Penyusunan persamaan alometrik untuk penaksiran cadangan karbon hutan berdasar pengukuran lapangan (ground based forest carbon accounting). Standar Nasional Indonesia SNI 7725:2011

Chave J, Réjou-Méchain M, Búrquez A, Chidumayo E, Colgan MS, Delitti WB, Duque A, Eid T, Fearnside PM, Goodman RC, Henry M, Martínez-Yrízar A, Mugasha WA, Muller-Landau HC, Mencuccini M, Nelson BW, Ngomanda A, Nogueira EM, Ortiz-Malavassi E, Pélissier R, Ploton P, Ryan CM, Saldarriaga JG, Vieilledent G (2014) Improved allometric models to estimate the aboveground biomass of tropical trees. Global Change Biol 20:3177-3190

Feldpausch TR, Affum-Baffoe K, Alexiades M, Almeida S, Amaral I, Andrade A, Aragão LEOC, Murakami AA, Arets EJMM, Arroyo L, Aymard CGA, Lloyd J, Baker TR, Bánki OS, Berry NJ, Cardozo N, Chave J, Comiskey JA, Dávila EA, Oliveira A, DiFiore A, Djagbletey G, Lewis SL, Domingues TF, Erwin TL, Fearnside PM, França MB, Freitas MA, Higuchi N, Honorio CE, lida Y, Jiménez E, Kassim AR, Brienen RJW, Killeen TJ, Laurance WF, Lovett JC, Malhi Y, Marimon BS, Marimon-Junior BH, Lenza E, Marshall AR, Mendoza C, Metcalfe DJ, Gloor E, Mitchard ETA, Nelson BW, Nilus R, Nogueira EM, Parada A, Peh KSH, Cruz AP, Peñuela MC, Pitman NCA, Prieto A, Mendoza AM, Quesada CA, Ramírez F, Ramírez-Angulo H, Reitsma JM, Rudas A, Saiz G, Salomão RP, Schwarz M, Silva N, Silva-Espejo JE, Lopez-Gonzalez G, Silveira M, Sonké B, Stropp J, Taedoumg HE, Tan S, Steege H, Terborgh J, Torello-Raventos M, Heijden GMFVD, Vásquez R, Banin L, Vilanova E, Vos V, White L, Wilcock S, Woell H, Phillips OL, Salim KA (2012) Tree height integrated into pan-tropical forest biomass estimates. Biogeosciences 9:2567-2622

Goodman RC, Phillips OL, Baker TR (2014) The importance of crown dimensions to improve tropical tree biomass estimates. Ecol Appl 24:680-698

Griscom B, Ellis P, Putz FE (2014) Carbon emissions performance of commercial logging in East Kalimantan, Indonesia. Global Change Biol 20:923-937

Halperin J, LeMay V, Chidumayo E, Verchot L, Marshall P (2016) Model-based estimation of above-ground biomass in the miombo ecoregion of Zambia. Forest Ecosyst 3:14

Hansen MC, Stehman SV, Potapov PV, Arunarwati B, Stolle F, Pittman K (2009) Quantifying changes in the rates of forest clearing in Indonesia from 1990 to 2005 using remotely sensed data sets. Environm Res Lett 4:034001

Hashimoto T, Tange T, Masumori M, Yagi H, Sasaki S, Kojima K (2004) Allometric equations for pioneer tree species and estimation of the aboveground biomass of a tropical secondary forest in East Kalimantan. Tropics 14:123-130

Henry M, Besnard A, Asante W, Eshun J, Adu-Bredu S, Valentini R, Bernoux M, Saint-Andre L (2010) Wood density, phytomass variations within and among trees, and allometric equations in a tropical rainforest of Africa. Forest Ecol Manag 260:1375-1388

Hiratsuka M, Toma T, Diana R, Hadriyanto D, Morikawa Y (2006) Biomass recovery of naturally regenerated vegetation after the 1998 forest fire in East Kalimantan, Indonesia. Japan Agric Res Q 40:277-282

Hurvich CM, Tsai C-L (1989) Regression and time series model selection in small samples. Biometrika 76:297-307

lida Y, Poorter L, Sterck FJ, Kassim AR, Kubo T, Potts MD, Kohyama TS (2012) Wood density explains architectural differentiation across 145 co-occurring tropical tree species. Funct Ecol 26:274-282

IPCC (2006) 2006 IPCC guidelines for national greenhouse gas inventories. Intergovernmental Panel on Climate Change. Japan

Johnson KD, Birdsey R, Finley AO, Swantaran A, Dubayah R, Wayson C, Riemann R (2014) Integrating forest inventory and analysis data into a LIDAR-based carbon monitoring system. Carbon Balance Manage 9:3

Kartawinata K (2005) Six decades of natural vegetation studies in Indonesia. Naturindo Publication, Bogor

Krisnawati H, Adinugroho C, Imanuddin R, Hutabarat S (2014) Estimation of forest biomass for quantifying CO2 emissions in central Kalimantan: a comprehesive approach in determining forest carbon emission factors. Research and development center for conservation and rehabilitation. Forestry Research and Development Agency, Bogor

MacKinnon K (1996) The ecology of Kalimantan. Oxford University Press, Hong Kong

Manuri S, Brack C, Nugroho NP, Hergoualc'h K, Novita N, Dotzauer H, Verchot L, Putra CAS, Widyasari E (2014) Tree biomass equations for tropical peat swamp forest ecosystems in Indonesia. Forest Ecol Manag 334:241-253

Miettinen J, Shi C, Liew SC (2011) Deforestation rates in insular Southeast Asia between 2000 and 2010. Global Change Biol 17:2261-2270

MoEF (2015) National forest reference emission level for deforestation and forest degradation: In the context of decision 1/CP.16 Para 70 UNFCCC (encourages developing country parties to contribute to mitigation actions in the forest sector), Directorate general of climate change. The Ministry of Environment and Forestry, Indonesia

Muller-Landau HC (2004) Interspecific and inter-site variation in wood specific gravity of tropical trees. Biotropica 36:20-32

Newbery DM, Campbell E, Lee Y, Ridsdale C, Still M (1992) Primary lowland dipterocarp forest at Danum Valley, Sabah, Malaysia: structure, relative abundance and family composition. Philos Trans R Soc B 335:341-356

Onoda Y, Richards AE, Westoby M (2010) The relationship between stem biomechanics and wood density is modified by rainfall in 32 Australian woody plant species. New Phytol 185:493-501

Paoli GD, Curran LM, Slik JWF (2008) Soil nutrients affect spatial patterns of aboveground biomass and emergent tree density in southwestern Borneo. Oecologia 155:287-299

Vieilledent G, Vaudry R, Andriamanohisoa SF, Rakotonarivo OS, Randrianasolo HZ, Razafindrabe HN, Rakotoarivony CB, Ebeling J, Rasamoelina M, 2012. A universal approach to estimate biomass and carbon stock in tropical forests using generic allometric models. Ecological Applications 22:572-83

Picard N, Saint-André L, Henry M (2012) Manual for building tree volume and biomass allometric equations: from field measurement to prediction. Food and Agricultural Organization of the United Nations, Rome, and Centre de Coopération Internationale en Recherche Agronomique pour le Développement, Montpellier, p 215

Piñeiro G, Perelman S, Guerschman JP, Paruelo JM (2008) How to evaluate models: observed vs. predicted or predicted vs. observed? Ecol Modell 216:316-322

Samalca IK (2007) Estimates of forest biomass and its error: a case study in Kalimantan, Indonesia. Unpublished postgraduate thesis, International Institute for Geo-Information Science and Earth Observation, Enschede. http://www.itc.nl/library/papers_2007/msc/gem/samalca.pdf

Sileshi GW (2014) A critical review of forest biomass estimation models, common mistakes and corrective measures. Forest Ecology and Management 329:237-54

Sist P, Saridan A (1999) Stand structure and floristic composition of a primary lowland dipterocarp forest in East Kalimantan. J Trop Forest Sci. 11(4):704-22.

Snowdon P (1991) A ratio estimator for bias correction in logarithmic regressions. Canadian Journal of Forest Research 21:720-24

Soerianegara I, Lemmens R (1993) Plant resources of South-East Asia No. 5 (1) Timber trees: major commercial timbers. Centre for Agricultural Publishing and Documentation (PUDOC). Wageningen

UNFCCC (2015) Adoption of Paris agreement. UNFCCC. COP 21, Paris

van Breugel M, Ransijn J, Craven D, Bongers F, Hall JS (2011) Estimating carbon stock in secondary forests: decisions and uncertainties associated with allometric biomass models. Forest Ecol Manag 262:1648-1657

Williamson GB, Wiemann MC (2010) Measuring wood specific gravity... correctly. Am J Bot 97:519-524

Yamakura T, Hagihara A, Sukardjo S, Ogawa H (1986a) Aboveground biomass of tropical rain forest standsin Indonesian Borneo. Plant Ecol 68:71-82

Yuen JQ, Fung T, Ziegler AD (2016) Review of allometric equations for major land covers in SE Asia: uncertainty and implications for above- and below-ground carbon estimates. Forest Ecol Manag 360:323-340

Zanne A, Lopez-Gonzalez G, Coomes D, llic J, Jansen S, Lewis S, Miller R, Swenson N, Wiemann M, Chave J (2009) Global wood density database. http:// datadryad.org/handle/10255/dryad.235. (Accessed 1 Feb 2014)

\section{Submit your manuscript to a SpringerOpen ${ }^{\circ}$ journal and benefit from:}

- Convenient online submission

- Rigorous peer review

- Immediate publication on acceptance

- Open access: articles freely available online

- High visibility within the field

- Retaining the copyright to your article

Submit your next manuscript at springeropen.com 